\title{
Frontline
}

\section{An innovative direction in academic journalism}

\section{COMMIFNIARY}

The Pacific Media Centre-Te Amokura - which publishes Pacific Journalism Review has always been concerned to link 'robust and informed journalism' with media research that contributes to social development both in the broader community, the media industries and inside the academy. The new section Frontline aims to further this by addressing more directly the interface between professional or practice-based journalism and scholarly journalism research practices. This commentary reflects new directions in academic journalism. It is worth charting some of the developments that have brought us to this point.

\section{WENDY BACON}

Australian Centre for Independent Journalism

7 ME MAY edition of Pacific Journalism Review featured articles by two journalists, both about the investigation of mining issues in the

Pacific region. Both articles provided a scholarly commentary contextualising and reflecting on the journalism practices involved in producing major features originally for publication elsewhere. (Abplanalp, 2012; Gooch, 2012a). These two articles were the first contributions to what will be a new regular Frontline section in PJR. I will return to discuss them further.

The Pacific Media Centre-Te Amokura—which publishes this journal has always been concerned to link 'robust and informed journalism' with media research that contributes to social development both in the broader community, the media industries and inside the academy. Frontline aims to further this by addressing more directly the interface between professional or practice-based journalism and scholarly journalism research practices. This innovation reflects new directions in academic journalism. It is worth charting some of the developments that have brought us to this point. 
In the 1990s, journalism academics in Australia and New Zealand became embroiled in a debate which became known as 'The Media Wars' about whether there was room for a media studies focus in the education of journalists. A range of positions was adopted within this debate. On one side, Keith Windschuttle and some others, argued that journalism students should be insulated from media studies which he portrayed as a 'left-wing' cultural practice that was destructive of journalism, which required a realist view of the world and applied empirical methods of observation to produce factual clear writing. According to this view, critiques of the notion of objectivity and truth had little relevance for journalists (Windschuttle, 1998). On the other side of the debate, some cultural studies academics argued that journalism education tended to be restricted to training for increasingly corporate newsrooms and was overly technocratic. According to this view, the best literature on journalism was produced by those who had little to do with journalism itself (Hartley, 1996). Other journalism academics argued that if journalism was to thrive in the academy, it should involve both journalism practice as well as scholarly research and the study of journalism and that these distinct practices should be related to each other. Some within this group also tended to be critical of media and cultural studies perspectives that concentrated on textual and audience studies' approaches and failed to take sufficient account of journalism production, including investigative journalism, journalism documentary and alternative journalism practices.

The debates in our region mirrored similar debates in journalism education elsewhere (Skinner et al., 2001). UK academic Sarah Niblock, for example, noted that the rise of the journalism academic, who was often an experienced practitioner, was breaking down the 'once barricaded boundary lines between journalism practices and journalism theory'. She described a breed of new academics who were keen to conduct research but who argued that while textual analysis could reveal significant conclusions about editorial decisions, a study of journalism that excluded the experiences of those within the industry left 'many important and practical questions unanswered' (Niblock, 2007, p. 21).

Within their curricula, universities in the region had developed a range of teaching approaches which reflected underlying positions in relation to these debates about the relationship of 'practice and theory'. Even within institutions, different academics used different approaches.

The University of Technology, Sydney, degree in journalism programme, which I joined in 1991, had adopted a curriculum in which all students studied 
journalism practice and theory from the early 1980s onwards. For instance, Chris Nash, now the professor of journalism at Monash University, developed a course, News and Current Affairs, which reviewed, compared and critiqued a range of scholarly approaches towards journalism. As part of their assessment, students were required to produce an essay which drew on at least two of these approaches to analyse critically a piece of their own journalism practice. From 1991, Masters of Journalism coursework students had the option of producing either two related major works, one a piece of journalism practice plus a related scholarly research essay, or a conventional scholarly research thesis (Bacon,1999).

The 'Media Wars' debate and the desire to maintain my own practice of investigative journalism so that I could continue to be an effective teacher, led to me to explore these issues further by asking: "What is a journalist in a university?' This was published in a special issue of Media International Australia devoted to the 'Media Wars'. I wrote:

As a person who teaches scholarship around the media and journalism professional practice, I see both as forms of practice which are informed by theories and understandings about the world. I would argue that the assumptions and theories embedded in journalism as well as scholarship need to be made explicit so they can be understood. They cannot be treated as self-evident principles to be unthinkingly applied, although I agree with John Hartley that this has often been the case; they must be open to question like everything else. (Bacon, 1999 p. 82)

In this article, I laid out a number of case studies including, one by Phil Thornton, a journalist of 20 years' experience, in which a scholarly investigation identified a gap in reporting which preceded his journalism practice project. (Bacon, 1999 p. 85; Thornton, 1998a). The project was triggered by a tiny item which appeared in The Sydney Morning Herald on 16 September 1994: 'Mining ceased for several hours at the Tahmoor coal mine near Picton yesterday after miners found body parts in conveyor equipment about 1.25 km underground.' As Thornton explained: the 'brief lodged in my head' but nothing more appeared. One option could have been to provide an in-depth investigation of the incident. Instead, Thornton asked 'how do we as journalists cover work?' A 10-day scholarly content analysis and textual analysis of two stories demonstrated how little reportage was about the actual work that people do and the conditions in they do it. This was particularly so for blue- 
collar workers. The detail of even severe industrial accidents was mostly rendered invisible. As a step towards filling the void identified in his scholarly report, Thornton produced 10 features, each an interview and profile with an individual blue collar worker. Along with photojournalism by Phil Jones, these profiles were published in a series in the Fairfax Sunday paper The Sun-Herald (Thornton 1998b). The results of the scholarly research were published in the Australian Centre for Independent Journalism's Reportage and the whole project later appeared as a book (Thornton \& Jones,2000).

In another article produced for the same issue of Media International Australia, Michael Meadows, now professor of journalism at Griffith University, strenuously rejected the Windschuttle position and argued that journalism is a cultural resource which relies on its 'truth value' as a genre and offers itself to readers within this framework (Meadows, 1999). Students of journalism, whether interested in joining mainstream media or not, need to know how to analyse the practices that produce the journalism that makes such a significant contribution to the way in which we 'imagine' our communities and ourselves. He drew on five principles of journalistic design laid out by Stuart Adam (Meadows, 1999, p. 48; Adam, 1993, p. 45). These are news and news judgment, reporting or evidentiary method, linguistic technique, narrative technique, and method of interpretation or meaning. It is through the application of these principles that journalists base their 'truth claims', create meaning and produce knowledge. They can be applied to all forms of journalism from routine news to more ambitious forms of documentary, investigative and literary journalism. Meadows argued that using these principles, judgments can be made about 'the authority of its facts, the clarity and originality of its language, the utility and success of its narrative technique, and the degree to which journalists have penetrated, and thereby interpreted, the materials they have brought to light' (Meadows, 1999, p. 48) .

More than a decade on and with the heat now out of the debate, Meadows' article and other contributions to the MIA special issue bear rereading at this new current juncture in development of academic journalism.

Up to 2000, most of the discussion about the relationship between 'theory and practice' was devoted to its implications for journalism education. From this point, the discussion about what constituted research in the academy was moving on to consider whether forms of creative practice, including fictional writing, experimental documentary, visual arts and music composition, could 
also be constituted as academic research, alongside other forms of scholarly research. This debate was stimulated by a trend begun by the United Kingdom government's research institutions to measure and evaluate university-based research within a competitive framework. The trend was picked up in Australia and New Zealand. The move to competitive rankings led to increasing pressure on academics who wanted to maintain their creative and professional practice to find a home within these new frameworks of evaluation. To some extent journalism was a latecomer to these discussions, partly because of the marginalisation of journalism by those who promoted the view that journalism was non-reflexive and often routine and therefore could not itself be regarded a research practice.

This had the beneficial effect of encouraging journalism academics to spell out more clearly the argument that the practice of journalism through it is own research methodologies was a form of practice-based research undertaken to 'gain knowledge and understanding' which could lead to 'new or substantially improved insights...' (RAE, 2008). For example, I used a lengthy investigation into the wrongful conviction of Roseanne Catt (imprisoned for 10 years in NSW) to demonstrate how miscarriages of justice were more likely to be revealed by the lateral questioning and 'off the record' interviews of investigative journalism than by the conventional social science methods of criminology or legal research (Bacon, 2006a, 2006b).

Eventually the argument was accepted that journalism can constitute research within the institutional framework of the United Kingdom and Australian university systems but in New Zealand it is still a field evolving (Hannis, 2011). Much public relations driven and routine journalism does not fall into that category, an understanding which some Australian academics may have failed to grasp (Turner, 2011). However, for the time being at least, the ground has shifted to provide new opportunities for innovation and research-based journalism in the academy. In practice, the levels of acceptance of this new opportunity by both journalism academics and assessors have differed between countries, institutions and individual academics. In the first and second rounds of the Excellence in Research for Australia (ERA) evaluation, a number of universities have put forward works of journalism practice, each accompanied by short statements explaining the significance of the contribution of the research to knowledge and the methodologies and approach used (Bacon, 2011, p. 49). 
The situation remains fluid, however, as some senior journalism academics give little encouragement to practice-based research while other institutions are still nervous or reluctant to put forward unconventional research (Bromley, 2011). Frontline is one attempt to build experience and support for reflexive practice-based journalism research. It recognises and builds on the work of Edith Cowan University's peer-reviewed journal Research Journalism, an initiative led by Dr Kayt Davies, which aims to publish scholarly work that documents and analyses journalism methodological approaches, as well as practice-based research accompanied by scholarly reflections (researchjournalism.wordpress.com).

Meanwhile, journalism education curricula have continued to develop at many universities to include honours, masters by coursework and higher degrees. The majority of these also offer the possibility of advanced students of journalism producing media accompanied by scholarly exegeses ${ }^{1}$ or critical reflective analyses of the journalism work which may consist of one or more stories in any medium. These courses are increasingly attracting both people with extensive experience in other disciplines and also experienced journalists. Awards, including the Student Walkley, have also been developed which are designed to attract high quality journalism from young journalists. For example, the 2010 Student Walkley winner Lauren Day, who now works for the $\mathrm{ABC}$, did a video on climate change in Kiribati for the production component of her Honours thesis. This was accompanied by an exegesis which focussed on the selection of sources for her story in the context of a previous review of journalism studies' literature on sources. Her conclusion, based on her own experience, was that the scholarly research on sources does not adequately account for the selection of sources in features (Day, 2011).

Day's work provides just one example of the sort of peer-reviewed scholarly reflections or exegeses arising from journalism works by academics, journalists and advanced journalism students. In some cases, the journalism and scholarly work will be published alongside each other. In other cases, the scholarly analyses will be accompanied by transcripts and linked to web publications. In some cases, stand-alone journalism works will be published, especially where the methodologies used are transparent in the text or documented. For example, investigations using Freedom of Information laws can document the application trail and the interaction between actors in the stories. All material will be peer-reviewed by people with appropriate experience in the relevant field. 
The articles published in the last issue of PJR demonstrate two possible further approaches. Metro, a leading New Zealand glossy magazine reporting issues and society, published an investigative article 'Blood Money' by Karen Abplanalp probing the New Zealand Superannuation Fund (NZSF) investment in the controversial US-owned Freeport copper and gold mine at Grasberg as its lead feature in the December 2011 edition. She chose this investigation after observing that events in West Papua had been largely ignored by New Zealand mainstream media for four decades. In her investigation, the author sought to "establish how the NZSF laid claim to being a "responsible investor" while remaining involved in a mine with a long history of being implicated in alleged human rights violations and severe environmental damage' (Abplanalp, 2012, p.128). In her exegesis, she considers the merits of possible journalistic frameworks for her investigation and explains why she adopted the 'peace journalism' framework which she locates in the work of scholars including Dixit, Galtung and Robie (Galtung, 2003; Dixit, 2011; and Robie, 2011). She discussed how the peace journalism approach was applied through her reportage and methodology, which involved 'translation, cross-checking and analysing of public relations documents' that made up a lot of official responses. She conducted extra historical research in order to follow Galtung's recommendation that a historical perspective be included in peace journalism (Galtung, 2003). After publication, she analysed the public response and its relevance to her approach.

Gooch, who is bilingual in French and English, investigated a project by the world's second largest nickel producer Vale SA, which will soon begin production. The complete version was published in Pacific Journalism Review (Gooch, 2012b). A shorter edited version was published in the new independent online magazine Global Mail earlier this year (Gooch, 2012a). In her PJR article, 'Background to "Sulphate Sunrise" - investigating New Caledonia', Gooch examined the relevance to the conflict over the mine in the context of specific social, ethical, and spiritual perspectives which are 'deeply embedded in a broader political, economical and social framework - that of decolonisation and questions over legitimacy of power (Gooch, 2012b; drawing on Horowitz, 2009, p. 249; van Vuuren, 2008, p. 74). She then locates her investigation in the context of earlier research on the media coverage of Pacific Island nations. She supplemented this literature review with four interviews with experienced correspondents in the area who all expressed concern about the inadequacy of Australian coverage of the Pacific. 
These interviews confirmed previous research which showed that the superficiality of the small amount of coverage that existed was reflected in the use of a narrow range of (mostly official) sources (Gooch, 2012b, p. 152, drawing on Hall, 1978; Nash \& Bacon, 2002). Gooch then analyses her own experience in attempting to access more critical and grassroots sources in her investigation. She notes that even a French environmentalist who has lived in New Caledonia 'will have a radically different perspective on the environment to that of an indigenous Kanak, for whom land is first and foremost the source of identity and dignity'. Views within the Kanak community also diverged. Gooch's local knowledge also enabled her to access information about the mine that was not available to local opponents of the mine. On the other hand, she had considerable difficulty getting answers from official sources, which she documents in the story itself. She explores how these experiences supplemented the understanding she had gleaned from scholarly research into the over use of official and public relations sources in news journalism.

Each of these two articles were submitted by newer journalists completing major projects for postgraduate coursework degrees. Another approach can be seen in a recent article in Media International Australia by Bonita Mason, a lecturer in journalism at Curtin University, who won a Walkley award for her story 'The Girl in Cell Block 4' which investigated the last week in the life of an indigenous woman, Janet Beetson, who died an avoidable death in NSW Mulawa Womens' Prison in 1994 (Mason, 1997). Mason's original investigation has become the subject of a longer practice-led research project which draws on the conceptual tools of Pierre Bourdieu's theory of practice (Mason, 2012). 'Using the analytical and narrative techniques provided by Donald Schon (1991), [she] aims to find out how [her] own unorthodox practices might contribute to more conventional practice by extending the range of stories told, and the range of voices heard...' (Mason, 2012, p. 170). Her analysis begins with a review of the literature on the how indigenous citizens have traditionally lacked a voice in Australian media (Meadows \& Oldham,1991; Ewart, 2002) in the context of the broader literature on critiques of the norm of objectivity and broader social power relations and how these contribute to the exclusion of some voices. She uses this to analyse her own practice in relation to a key source for the story, Beetson's mother-in-law Dawn Delaney. Her approach was a collaborative one in which she drew on Shapiro's notion of 'levels of permission' (Schapiro, 2004). In her conclusion, Mason suggests 
that if journalists want to counter exclusion of marginal voices, they may need to reconsider professional norms which would usually not include 'solidarity and collaboration' (Mason, 2012, p. 174).

Any single journalistic investigation raises many possible avenues for reflective scholarly analysis. In considering doctoral projects in which the researcher plans from the beginning to produce both scholarly and journalistic research, Nash suggests the researcher begins by locating the journalistic research question within scholarly and journalistic debates about some aspects of the topic, eg. the empirical evidence, textual characteristics, the production process, the relationship to its own generic field of creative/professional practice from an industrial, political, economic perspective etc. Each of these aspects can generate a number of questions. For example, in considering empirical evidence that supports the 'truth claims' in the research, the researcher might ask: What evidence? Why was it chosen? How was it established? When and where? (spatio and temporal determinants); Who? (sources/players); and why were they chosen? What is their significance and their positional or vested interests? The visibility or invisibility of evidence. (Nash, 2012). One or more parts of a larger doctoral project might be adapted for peer-reviewed publication in Frontline.

These new possibilities for developing investigative and other forms of in-depth journalism come at a time when most would agree that mainstream journalism is in crisis. Very experienced journalists are being retrenched as the advertising that fed media corporations falls away, profits fall and new digital technologies are introduced. Some of these journalists are attracted to start or continue studying higher degrees in universities.

There are also possibilities for collaborative projects, across time and in more than one location (Bacon, 2011). Former Age investigative journalist Bill Birnbauer, who is now a Monash University academic, argued at the first regional investigative conference at the Pacific Media Centre in December 2010: 'The absence of corporate interference, government control, daily deadlines or the need to produce quality investigative journalism', along with the presence of 'academic staff with significant levels of experience in the production of journalism' places universities in a strong position to produce quality investigative journalism (Birnbauer, 2011, p. 26).

Birnbauer analysed the potential for collaborative investigative journalism in light of the history of non-profit journalism, the growing incapacity 
of mainstream media to pursue investigative projects without external support and the development of a new non-profit ecosystem of investigative journalism in the United States. Drawing inspiration from United States based organisation, the International Consortium of Investigative Journalists, he proposed a Unimuckraker, a collaboration across universities in our region. So far the resources have not been available for such a project, but individual institutions have developed group projects including Fairfax/UTS recent collaboration Polly Perks, a systematic investigation into gifts to politicians (Washington et al., 2012) and collaboration between Crikey.com and Swinburne University's Brumby and Baillieu Dumps (Simons et al., 2011; Dodd Green, 2011) and Crikey.com and the Australian Centre for Inde[pendent Journalism's Reportage Online (Le et al. 2011). Birnbauer himself has developed Dangerous Ground (Monash University, 2012), an on-going project which systematically investigates the management of toxic waste by the Victorian Environmental Agency. This text and video project has already broken stories in mainstream media but perhaps more importantly provides an on-going public record that scrutinises and makes accountable a key government body...'

In various ways, media freedom continues to be constrained by the political and social realities, whether commercial or political, across our region. Projects like Dangerous Ground and other similar ones are evidence that the production of university-based journalism research can contribute to a more open, independent and diverse media.

A parallel and key task of university-based journalism research is to archive, document and critically analyse our own innovations, including practice-based publishing projects and in-depth journalism research. David Robie wrote in 2002: 'The study of an independent student press and online or broadcast media in the Pacific has been neglected and rarely raised in any industry debate on media freedom'. In 2010, in further scholarly research, he reflected in a UNESCO Media Freedom Day address on university-based journalism production from 1975 until then. He had interviewed students who had been involved in reporting on the George Speight coup a decade earlier in Fiji in May 2000, which led to the University of South Pacific journalism website being closed down by the vice-chancellor (Frontline Reporters, 2000). At the time, the Australian Centre for Independent Journalism continued to publish the student material (ACIJ Crisis Coverage, 2000). The then ACIJ director, Professor Chris Nash, said that for academic journalists to do anything else 
would be 'unconscionable'. Robie found that in many respects the experience of the young student reporters in university-based courses was 'more independent than the mainstream commercial media driven by profit' and that for some 'the sheer experience was worth a three-year degree'. (Robie, 2010, p. 123). Robie's analysis provides a strong example of how practice-based journalism teaching needs to be considered as part of the media sphere, including an evolving body of practice-based journalism and scholarly research work. The original publication about the Speight coup is available for further research (ACIJ, 2000).

Over the last two decades, the history of journalism research in universities has been a dynamic and intellectually rewarding one. I have suggested some possibilities but more will emerge. As they do, Frontline will build a public archive of examples of journalism research and exegeses to assist those who embark on the challenging process of critiquing their own work. New forms linking different forms of knowledge production through and about journalism are certain to emerge.

\section{Note}

1. Exegesis, from the Greek word for 'lead out' involves a critical interpretation of a text to draw out its meaning. It involves a subsequent or parallel analysis of a text in another text and genre than the primary text, eg. a scholarly exegesis of an investigative journalism video. It involves the ability to situate chosen aspects of a text within a nominated disciplinary and theoretical framework.

\section{References}

Abplanalp, Karen (2012). 'Blood Money': A NZ investigative journalism case study. Pacific Journalism Review, 18(1), 128-147.

ACIJ (2000). Crisis coverage of the 2000 Fiji coup available in digital form [Archive of University of the South Pacific journalism students who covered the George Speight attempted coup]. Retrieved on September 21, 2012, from http://datasearch2. uts.edu.au/acij/news-events/news-detail.cfm?ItemId=31951

Bacon, W. (1997). Shifting notions of the public in journalism. Culture and Policy, $8(2), 65-91$.

Bacon, W. (1998). Engaging theory and practice in journalism education. Asia Pacific Media Educator, 1(1), 144-152.

Bacon W. (1999). What is a journalist in a university? Media International Australia, 92(1), 79-90.

Bacon, W. (2006a). Journalism as research. Australian Journalism Review, 28(2), 147-157. 
Bacon, W. (2006b). Journalism as research? Thinking about journalism research in an Australian context. Pacific Media Centre Online. Retrieved on September 21, 2012, from www.pmc.aut.ac.nz/research/journalism-research-thinking-aboutjournalism-research-australian-context

Bacon, W. (2011). Investigative journalism in the academy-possibilities for storytelling across time and space. Pacific Journalism Review, 17(1), 45-66.

Birnbauer, W. (2011). Student muckrakers: Applying lessons from non-profit investigative reporting in the US. Pacific Journalism Review, 17(1), 26-44.

Bromley, M., and Regan, N. (2011). Publishing participation and productivity among journalist-academics in the era of ERA. Australian Journalism Review, 33(1), $55-72$.

Crikey/Australian Centre for Independent Journalism (2010). Spinning the media-A joint Crikey-ACIJ Investigation. Retrieved on November 12, 2010, from www. crikey.com.au/spinning-the-media/

Day, L. (2011). Kiribati Climate Change-'We are not refugees'. [Video with exegesis]. Retrieved on September 16, 2012, from www.pmc.aut.ac.nz/research/ kiribati-climate-change-we-are-not-refugees.

Dixit, K. (2011). Real investigative journalism in a virtual world. Pacific Journalism Review, 17(1), 12-19.

Dodd, A., and Green, S. (2011, October 24). The Baillieu dump: More accountability, but same tactics from Ted. Crikey.com. Retrieved on September 16, 2012, from www.crikey.com.au/2011/10/24/the-baillieu-dump-more-accountability-but-sametactics-from-ted/

Frontline Reporters: Student journalists cover Fiji coup (2000). [Video documentary, 12 min]. Suva: USP Journalism Programme.

Gooch, N. (2012a, April 27). Nickel and Maligned. Global Mail. Retrieved on September 10, 2012, from www.theglobalmail.org/feature/nickel-and-maligned/214/

Gooch, N. (2012b). Background to 'Sulphate Sunrise'-investigating New Caledonia. Pacific Journalism Review, 18(1), 148-170.

Hannis, G. (2011). Creating a research culture at New Zealand university-based journalism programs, Australian Journalism Review, 33(1), 49-52.

Le, J., Davis, M., Pitrova, V., and Simona, S. (2011, August 10, 11, 12). The public health crisis no-one wants to know about. Reportage Online. Retrieved on September 18, 2012, from www.reportageonline.com/2011/08/the-public-health-crisisno-one-wants-to-know-about/

Monash University Arts Faculty (2012). Dangerous ground - The EPA's toxic legacy. Retrieved on September 20, 2012, from http://epadangerousground.com/

Morton, Tom (2012). 'Dirty little secret': Journalism, privacy and the case of Sharleen Spiteri. Pacific Journalism Review, 18(1), 46-68.

Nash, C. and Bacon, W. (2002). News/WORTHY: How the Australian media cover humanitarian, aid and development issues. Retrieved on September 16, 2012, from www.ausaid.gov.au/publications/Documents/newsworthy.pdf..

Nash, C.( 2012). Unpublished lecture, September 10. 
Niblock, S. (2007). From 'knowing how to being able'. Journalism Practice, 1(1), 20-32.

Nightingale, D. and Cromby, J. ( 1999). Social constructionist psychology: A critical analysis of theory and practice. Buckingham, United Kingdom: Open University Press.

Research Assessment Exercise 2008. (2008) Annex B. (ii) p. 22. Retrieved on 20 April 2011, from www.rae.ac.uk/pubs/2005/03/rae0305.doc - 2005-06-28

Robie, D. (2002). Cyberspace news on campus: The South Pacific experience. AsiaPacific MediaEducator, No 12/13, 203-19.

Robie, D. (2010). Pacific freedom of the press: Case studies in independent campusbased media models. Pacific Journalism Review, 16(2), 92-196. Retrieved on September 21, 2012, from www.pjreview.info/articles/pacific-freedom-press-casestudies-independent-campus-based-media-models-547

Robie, D. (2011). Conflict reporting in the South Pacific: Why peace journalism has a chance, The Journal of Pacific Studies, 32(2), 221-240.

Simons, M., Dodd, A., and Muller, D. (2010, November 19). The Brumby dump: How it all came out in the wash. Crikey.com. Retrieved on September 18, 2012, from www.crikey.com.au/2010/11/19/the-brumby-dump-how-it-all-came-out-inthe-wash/

Skinner, D., Gasher, M. and Compton, J. (2001). Putting theory into practice: A critical approach to journalism studies. Journalism, 2(3), 341-360.

Thornton, P. (1998a). Work - why you won't read all about it. Reportage, Spring.

Thornton, P. (1998b). Moral dilemmas, Sun-Herald. October/November.

Thornton, P. and Jones, P. ( 2000). It's only a job. Frenchs Forest, NSW: New Holland.

Turner, G. (2011). The ERA and journalism research. Australian Journalism Review, 33 (1), 5-7.

Ward, S. J. A. (2005). The invention of journalism ethics: The path to objectivity and beyond. Montreal: McGill Queen's University Press.

Washington, S., Allard, T., Bull, L., Hooke, P., Mao, F. Radulova, L. \& Young, N. (2012). Revealed: Politicians' gifts, trips and tickets. The Age. Retrieved on September 12, 2012, from www.theage.com.au/national/political-interests.

Windschuttle, K. (1998). Journalism versus cultural studies. Keynote address at the Media Wars: Media Studies and Journalism Education Seminar, Queensland University of Technology, November 27.

Professor Wendy Bacon, who is an editorial board member of Pacific Journalism Review and on the advisory board of the Pacific Media Centre, has been appointed editor of the new Frontline section of PJR.

wendybacon@gmail.com 